\title{
U očekivanju opadanja religioznosti? Komparativna analiza religioznosti zagrebačkih studenata
}

\author{
Krunoslav Nikodem
}

Sveučilište u Zagrebu, Filozofski fakultet, Odsjek za sociologiju, Hrvatska e-mail:knikodem@ffzg.hr

\section{Juraj Jurlina}

Sveučilište Josipa Jurja Strossmayera u Osijeku, Filozofski fakultet, Studij sociologije, Hrvatska

e-mail: jjurlina@ffos.hr

\begin{abstract}
SAŽETAK Rad se temelji na analizi rezultata empirijskog istraživanja provedenog u razdoblju od siječnja do travnja 2017. godine na prigodnom uzorku studenata Sveučilišta u Zagrebu i Hrvatskog katoličkog sveučilišta $(N=1270)$. Istraživanje je provedeno metodom ankete (grupno anketiranje) na studentima od prve do pete, odnosno šeste godine na trima sastavnicama Sveučilišta u Zagrebu (Filozofski fakultet, Fakultet strojarstva i brodogradnje i Medicinski fakultet) te na četirima odjelima Hrvatskog katoličkog sveučilišta (sociologija, psihologija, povijest i komunikologija). Osnovni cilj rada prezentacija je i analiza religioznosti zagrebačkih studenata temeljem dvaju empirijskih istraživanja koja su provedena 2005. i 2017. godine. U radu se polazi od opće pretpostavke o sukladnosti religijskih promjena kod jednog dijela zagrebačkih studenata s religijskim promjenama koje su prisutne kod opće populacije u Hrvatskoj. U radu su postavljene tri radne hipoteze koje pretpostavljaju: prvo, da su studenti HKS-a skloniji kršćanskoj religioznosti od studenata SVZG-a; drugo, da su studentice sklonije kršćanskoj religioznosti od studenata; treće, da je kršćanska religioznost studenata snažno povezana s njihovim političkim orijentacijama. Rezultati analize potvrđuju prvu i treću radnu hipotezu.
\end{abstract}

Ključne riječi: religioznost, studenti, političke orijentacije, društvene promjene, religijske promjene. 


\section{Uvod}

Analiza razvoja društva u sociologiji označena je modernizacijskom paradigmom koja, između ostalog, uglavnom pretpostavlja i procese sekularizacije, odnosno procese smanjivanja društvene i individualne važnosti religije. Smatralo se da će razvoj društva, prije svega kroz strukturalnu diferencijaciju, dovesti do ukidanja većine društvenih funkcija i javnih uloga religije i povlačenja religije u privatnu sferu i intimu pojedinca (Wilson, 1966.; Berger, 1990.; Luckmann, 1967.; Bruce, 2002.; Dobbelaere, 2002.). Procesi sekularizacije i privatizacije društva i religije desetljećima su bili u središtu kako sociologijske teorije uopće tako i teorija i empirijskih istraživanja u području sociologije religije. No u posljednjih tridesetak godina sve su brojnije kritike navedenih teza i sve se više dovode u pitanje postavke da „više modernizacije znači manje religije" i da se religija pod utjecajima procesa modernizacije povlači iz javne sfere. Tako Jose Casanova 1994. godine uvodi pojam deprivatizacije religije (Casanova, 1994.), a Peter Berger 1999. godine ističe procese desekularizacije (Berger, 1999., 2002.), da bi početkom 21. stoljeća Jürgen Habermas istaknuo koncept poslijesekularnog društva, gdje se religija javlja kao važan izvor smisla i motivacije u pomoći pri sučeljavanju s prijeporima globalnog kapitalizma (Habermas, 2008.). S tim u vezi Peter Beyer navodi da globalizacija društva, koja strukturalno potiče privatizaciju religije, također otvara prostore za obnovljeni javni utjecaj religije (Beyer, 1994.). Više je razloga za taj obnovljeni javni utjecaj religije i za „novu vidljivosti“ religije u suvremenom zapadnom društvu. Jedan je od njih i sve veća uloga religijskih institucija i zajednica u europskom socijalnom sustavu kao posljedica slabljenja i urušavanja socijalne države, iako je ta uloga bila važna i prije slabljenja socijalne države. Drugi je rastuća kriza povjerenja u sekularizam povezana s izazovima razvoja bioznanosti i biotehnologije i gubitkom vjere u sekularne utopije. Treći je razlog globalni terorizam i rat protiv terorizma, gdje se religija ne promatra kao moguće rješenje socijalnih problema, već kao socijalni, politički i ekonomski problem. Četvrti je razlog deregulacija medijskog tržišta i razvoj novih informacijsko komunikacijskih tehnologija koje omogućavaju brzo širenje religijskih simbola i diskursa (Hjelm, 2015.). S druge strane, navedeni „povratak religije“ u javnost suvremenog zapadnog društva nije prošao bez prijepora i problema, kako za samu religiju (ili religije) tako i za društvo u cjelini. Pritom se često ističu pitanja i problemi financiranja religijskih institucija i zajednica, povećane kontrole države te sve veći pritisci za prilagođavanjem tržišnim uvjetima (Martikainen, Gauthier, 2013.). Stoga je važno upozoriti da veća javna vidljivost religije ne znači nužno i veći utjecaj religije u društvu (Turner, 1991.; Hjelm, 2015.). To upozorenje posebice je važno za suvremeno hrvatsko društvo, koje posljednjih godina, između ostalog, karakteriziraju i izraziti sukobi između religijskog i sekularnog svjetonazora u gotovo svim područjima društvenog života, od kulture, obrazovanja, medija i javnosti do spolnosti, braka i obitelji te neizostavnih povijesti i politike. Analiza razloga i uzroka tih sukoba nije tema ovog rada i svakako bi prelazila njegove okvire, no u navedenom kontekstu izraženog sučeljavanja svetog i svjetovnog važno je, između ostalog, istaknuti i osnovne karakteristike „religijske slike“ suvremenog hrvatskog društva.

Prema rezultatima recentnog empirijskog istraživanja koje je za područje Srednje i Istočne Europe od lipnja 2015. do srpnja 2016. godine proveo Pew Research Center 
u Hrvatskoj je 84 posto izjašnjenih katolika, 86 posto iskazuje vjeru u Boga, 40 posto moli svaki dan, 24 posto tjedno odlazi na misu, a 76 posto ističe da im je „religija važna u životu“ (Pew Research Center, 2017.). Rezultati dobiveni empirijskim istraživanjem u sklopu velikog međunarodnog projekta European Values Study ${ }^{1}$ za 2008. godinu pokazuju da je prije deset godina u Hrvatskoj bilo 80,6 posto katolika, 79 posto ih se smatralo „religioznim osobama“, 87 posto ih je iskazivalo vjeru u Boga, 26 posto ih je tjedno odlazilo na misu, a za 70,3 posto religija je važna u njihovom životu (Črpić, Zrinščak, 2010.:8-14). Rezultati istog istraživanja za 1999. godinu pak pokazuju da je prije 19 godina u Hrvatskoj bilo 86,8 posto izjašnjenih katolika, 79,9 posto ih se smatralo „religioznim osobama“, u Boga je vjerovalo 91,4 posto, a na tjednu misu je odlazilo 31,4 posto i njih 77,2 posto je isticalo važnost religije u životu (Črpić, Zrinščak, 2005.).

Kraći pregled osnovnih rezultata empirijskih istraživanja religioznosti u hrvatskom društvu u posljednjih dvadesetak godina navodi na pitanja postoje li uopće promjene u području religioznosti nakon procesa „religijske revitalizacije“ (Zrinščak, 2001.) potaknutog društveno-političkim promjenama s kraja osamdesetih i početkom devedesetih godina prošlog stoljeća te kakva je u tom kontekstu slika religioznosti mladih, kao dijela opće populacije koji je više otvoren društvenim promjenama i manje sklon uvriježenim obrascima društvenog života. Možemo li religioznost mladih promatrati kao određeni indikator religijskih promjena (Zrinščak, 2001.) u društvu? I ako možemo, u kojem se smjeru kreću te promjene?

U ovom radu pokušat ćemo odgovoriti na navedena pitanja analizirajući rezultate vlastitog empirijskog istraživanja koje smo proveli od siječnja do travnja 2017. godine te uspoređujući dio dobivenih rezultata s rezultatima empirijskog istraživanja koje smo proveli 2005. godine (Nikodem, 2005.). Empirijska istraživanja u objema navedenim godinama provedena su na prigodnim uzorcima zagrebačkih studenata. Izbor takvog tipa uzorka, odnosno uzoraka, proizlazi iz nekoliko razloga. Prvo, studenti su prepoznatliiva podskupina mladih, čija brojnost kroz procese masovnog visokog obrazovanja raste. Drugo, studenti su podskupina mladih koja se obrazuje za specifična, visokostručna zanimanja, a završetkom procesa obrazovanja pripadat će najobrazovanijem dijelu populacije, iz kojeg se uglavnom regrutira društvena elita (Ilišin, 2014.:15). Treće, studenti su podskupina mladih koja je izrazito osjetljiva na društvene promjene, a time su i potencijalni pokretači novih trendova. Prigodnost uzorka proizlazi iz jednostavnih razloga dostupnosti i nedostatka financijskih sredstava za neki drugi tip uzorka koji bi nam omogućio provođenje empirijskog istraživanja čiji bi nam rezultati onda omogućili generaliziranje na cjelokupnu populaciju studenata ili mladih u Hrvatskoj. Nadalje, odabir fakulteta i sveučilišta čiji studenti čine uzorak istraživanja slijedio je logiku obuhvaćanja različitih znanstvenih područja koliko je to bilo moguće. Tako smo 2005. godine u uzorku imali studente pet sastavnica Sveučilišta u Zagrebu, koje su obuhvaćale četiri različita znanstvena područja: Filozofski fakultet i Katolički bogoslovni fakultet (područje društvenih i humanističkih znanosti), Prirodoslovno-matematički fakultet (područje prirodnih

1 Dalje u tekstu koristit ćemo skraćenicu EVS. 
znanosti), Fakultet strojarstva i brodogradnje (područje tehničkih znanosti) i Medicinski fakultet (područje biomedicine i zdravstva). U drugom valu tog istraživanja, 2017. godine, uzorak sadržava studente triju sastavnica Sveučilišta u Zagrebu i četiriju odjela Hrvatskog katoličkog sveučilišta, koji obuhvaćaju tri različita znanstvena područja: Filozofski fakultet i Hrvatsko katoličko sveučilište (područje društvenih i humanističkih znanosti), Fakultet strojarstva i brodogradnje (područje tehničkih znanosti) i Medicinski fakultet (područje biomedicine i zdravstva). U uzorak za istraŽivanje 2017. godine uključili smo studente Hrvatskog katoličkog sveučilišta kao svojevrsnu zamjenu za studente Katoličkog bogoslovnog fakulteta, koji nisu uključeni u uzorak za navedenu godinu. Pritom smo pretpostavili da će studenti Hrvatskog katoličkog sveučilišta imati višu razinu religioznosti od studenata u istraživanje uključenih sastavnica Sveučilišta u Zagrebu. S obzirom na to da je istraživanje provedeno 2017. godine jedno od prvih empirijskih istraživanja koja su provedena na studentima Hrvatskog katoličkog sveučilišta, za navedenu pretpostavku nismo imali utemeljenje u rezultatima prethodnih istraživanja. Stoga smo tu pretpostavku temeljili na specifičnim razlikama misije, vizije i sustava vrijednosti navedenih sveučilišta. ${ }^{2}$ Navedenom konstrukcijom uzorka težili smo postići što potpuniju sliku religioznosti ispitanih zagrebačkih studenata uz stalnu napomenu ograničenja dobivenih rezultata upravo zbog takvog uzorka. ${ }^{3}$

Rad se, osim ovog prvog i uvodnog dijela, sastoji od četiriju dijelova i zaključka. U drugom dijelu izlažu se metodološke napomene vezane uz uzorak i provedbu empirijskog istraživanja, korištene mjerne instrumente, cilj rada i osnovne hipoteze te metode obrade i analize podataka. Treći dio rada sadrži analizu religijske samoidentifikacije, četvrti dio sadrži analizu institucionalne religijske prakse, a u petom dijelu analiziraju se sustavi vjerovanja.

Na osnovnoj razini analiza uglavnom slijedi sljedeći obrazac - prvo se izlažu dobiveni rezultati istraživanja na prigodnom uzorku studenata iz 2017. godine, a zatim se ti rezultati, ukoliko je to moguće, uspoređuju s rezultatima istraživanja na prigodnom uzorku studenata iz 2005. godine. Dobiveni rezultati za 2017. godinu, prema

2 U misiji Hrvatskog katoličkog sveučilišta ističe se, između ostalog, „potraga za istinom kroz istraživanja, te očuvanje i prenošenje znanja za dobrobit društva, pri čemu osobitu pozornost posvećujemo odgoju cjelovite osobe u katoličkoj tradiciji i duhovnosti na temelju Apostolske konstitucije o katoličkim sveučilištima Ex corde Ecclesiae", dok se u misiji i ciljevima Sveučilišta u Zagrebu između ostalog ističe: „Sveučilište će njegovati principe moralnosti, etičnosti i tolerancije kako bi se studenti kroz studije formirali kao sudionici modernoga demokratskoga i multikulturalnoga društva" - više vidjeti na mrežnim stranicama tih Sveučilišta: www.unicath.hr i www.unizg.hr.

3 Promjene u uzorku istraživanja za 2017. godinu u odnosu na uzorak iz 2005. godine uglavnom su praktične naravi i proizlaze iz (trenutno) veće dostupnosti pojedinih sastavnica SVZGa (i HKS-a) u odnosu na neke druge sastavnice SVZG-a. Važno je napomenuti da je provedba istraživanja prethodno odobrena od Povjerenstva Odsjeka za sociologiju za prosudbu etičnosti istraživanja (2017-03) te da su za provedbu ovog istraživanja dobivena odobrenja i od Etičkih povjerenstava Medicinskog fakulteta Sveučilišta u Zagrebu, Fakulteta strojarstva i brodogradnje Sveučilišta u Zagrebu te Hrvatskog katoličkog sveučilišta. 
određenim pitanjima, uspoređuju se i s rezultatima za opću populaciju te s rezultatima drugih istraživanja koja su provedena na uzorcima mladih i studenata. Daljnja analiza, na rezultatima dobivenima 2017. godine, uključuje pregled i usporedbu dobivenih rezultata prema pripadnosti fakultetu ili sveučilištu te regresijsku analizu pojedinih čestica kao kriterijskih varijabli i osnovnih sociodemografskih karakteristika ispitanih studenata kao prediktorskog sklopa, kao i neke dodatne analize.

\section{Metodološke napomene}

\subsection{Uzorak}

Rad se temelji na analizi rezultata empirijskog istraživanja provedenog u razdoblju od siječnja do travnja 2017. godine na prigodnom uzorku studenata Sveučilišta u Zagrebu i Hrvatskog katoličkog sveučilišta $(N=1270)$. Istraživanje je provedeno metodom ankete (grupno anketiranje) na studentima od prve do pete, odnosno šeste godine na trima sastavnicama Sveučilišta u Zagrebu (Filozofski fakultet, Fakultet strojarstva i brodogradnje i Medicinski fakultet) te na četirima odjelima Hrvatskog katoličkog sveučilišta (sociologija, psihologija, povijest i komunikologija). U tablici 1 donosimo pregled uzorka prema osnovnim sociodemografskim karakteristikama.

Tablica 1.

Struktura uzorka prema osnovnim sociodemografskim karakteristikama.

\begin{tabular}{|l|c|c|l|l|c|}
\hline SPOL & $\mathrm{N}$ & $\%$ & VELIČINA NASELJA ODRASTANJA & $\mathrm{N}$ & $\%$ \\
\hline Žensko & 815 & 64,2 & Do 2000 stanovnika & 142 & 11,2 \\
\hline Muško & 452 & 35,6 & $2001-10000$ & 221 & 17,4 \\
\hline b.o. & 3 & 0,2 & $10001-50000$ & 269 & 21,2 \\
\hline FAKULTET/SVEUČILIŠTE & $\mathrm{N}$ & $\%$ & $50001-500000$ & 160 & 12,6 \\
\hline FFZG & 244 & 19,2 & Više od 500000 & 446 & 35,1 \\
\hline HKS & 487 & 38,3 & b.o. & 32 & 2,5 \\
\hline FSB & 240 & 18,9 & STUPANJ OBRAZOVANJA MAJKE & $\mathrm{N}$ & $\%$ \\
\hline MEF & 298 & 23,5 & Osnovna škola & 45 & 3,5 \\
\hline b.o. & 1 & 0,1 & Srednja škola & 571 & 45,0 \\
\hline GODINA STUDIJA & $\mathrm{N}$ & $\%$ & Viša, visoka škola (mr., dr.) & 607 & 47,8 \\
\hline Prva & 482 & 38,0 & b.o. / n.z. & 47 & 3,7 \\
\hline Druga & 176 & 13,9 & STUPANJ OBRAZOVANJA OCA & $\mathrm{N}$ & $\%$ \\
\hline Treća & 258 & 20,3 & Osnovna škola & 35 & 2,8 \\
\hline Četvrta & 112 & 8,8 & Srednja škola & 556 & 43,8 \\
\hline Peta & 78 & 6,1 & Viša, visoka škola (mr., dr.) & 622 & 49,0 \\
\hline Šesta & 161 & 12,7 & b.o. / n.z. & 57 & 4,5 \\
\hline b.o. & 0,2 & & & \\
\hline
\end{tabular}


Kako je vidljivo iz tablice 1, u uzorku je s obzirom na spol više studentica nego studenata, što je i razumljivo s obzirom na to da unutar ispitivanih studijskih grupa, osim na Fakultetu strojarstva i brodogradnje, prevladavaju studentice. S obzirom na godinu studija u uzorku ima najviše studenata prve godine, a gotovo $2 / 3$ uzorka čine studenti preddiplomskih studija, a 1/3 studenti diplomskih studija (ili viših godina integriranih studija). Nešto više od trećine ispitanih studenata dolazi iz Zagreba, a najmanje ih je iz manjih naselja (do 2000 stanovnika). Roditelji ispitanih studenata imaju podjednake razine obrazovanja.

\subsection{Mjerni instrumenti}

U analizi religioznosti zagrebačkih studenata većim dijelom koristimo standardizirane mjerne instrumente za mjerenje različitih dimenzija religioznosti koji su korišteni u longitudinalnim međunarodnim istraživačkim projektima. Tako za mjerenje religijske samoidentifikacije koristimo mjerni instrument preuzet iz međunarodnog istraživačkog projekta Aufbruch I, gdje skala od pet stupnjeva, uz „religiozno nesigurne“, „nereligiozne“ i „protivnike vjere“, sadrži razlikovanje unutar onih ispitanika koji se smatraju „religioznima“, i to na „religiozne u skladu s crkvenim učenjem“ i „religiozne na svoj način“. Navedeni mjerni instrument do sada je korišten u trima empirijskim istraživanjima koja su provedena na reprezentativnim uzorcima za opću populaciju Hrvatske, što otvara mogućnost barem djelomične usporedbe. Istraživanje koje smo proveli 2005. godine na prigodnom uzorku zagrebačkih studenata nažalost nije sadržavalo taj mjerni instrument. ${ }^{4}$ Nadalje, za mjerenje institucionalne religijske prakse koristimo standardizirani mjerni instrument preuzet iz međunarodnog istraživačkog projekta EVS. ${ }^{5}$ Nažalost upitnik iz 2005. godine nije sadržavao ni taj mjerni instrument. Za mjerenje različitih sustava vjerovanja koristimo mjerni instrument koji se sastoji od ukupno dvadeset čestica, koje sadržajno obuhvaćaju osnove kršćanskog vjerovanja, praznovjerje i vjerovanje koje smo nazvali „kozmička ireligija“, a koje sadržajno pripada području nekršćanske duhovnosti. Čestice koje obuhvaćaju kršćansko vjerovanje i praznovjerje djelomično su, uz manje izmjene, preuzete iz Aufbrucha I, a dio koji obuhvaća „kozmičku ireligiju“ samostalno smo konstruirali za potrebe istraživanja 2005. godine. Isti mjerni instrument korišten je i u istraživanju 2005. godine te u radu dajemo komparativnu analizu dobivenih rezul-

\footnotetext{
${ }^{4}$ Osnovna tema tih istraživanja stavovi su studenata o bioetičkim pitanjima kao što su eutanazija, genetički inženjering, pobačaj, medicinski potpomognuta oplodnja, poslijeljudski oblici života i smisao života i smrti. Stoga pitanje religioznosti obuhvaća tek jedan manji dio mjernih instrumenata u upitniku.

5 „Ako se izuzmu izuzetne prilike kao vjenčanja, pogrebi, krštenja i slično, koliko često pohađate vjerske obrede? - 1. Nikada; 2. Jednom u nekoliko godina; 3. Više puta godišnje (za velikih blagdana); 4. Jednom mjesečno; 5. Jednom tjedno; 6. Gotovo svakodnevno; 7. Nisam vjernik“. European Values Study međunarodni je longitudinalni istraživački projekt o osnovnim sustavima vrijednosti, unutar kojeg se od 1981. godine provode terenska istraživanja svake devete godine. Hrvatska se u projekt uključila u trećem valu, 1999. godine. Nakon obavljenog četvrtog vala 2008. godine, terenski rad u petom valu provodi se upravo dok pišemo ovaj rad. Za više informacija o tom projektu vidjeti na http://www.europeanvaluesstudy.eu/.
} 
tata. Navedene dimenzije religioznosti analiziramo s obzirom na jedan prediktorski sklop koji obuhvaća osnovne sociodemografske karakteristike i političke orijentacije ispitanika. ${ }^{6}$

\subsection{Cilj rada i hipoteze}

Osnovni cilj rada prezentacija je i analiza religioznosti zagrebačkih studenata temeljem dvaju empirijskih istraživanja koja su provedena 2005. i 2017. godine. U radu polazimo od opće pretpostavke o sukladnosti religijskih promjena kod dijela zagrebačkih studenata s religijskim promjenama koje su prisutne kod opće populacije u Hrvatskoj. Naime rezultati dosadašnjih empirijskih istraživanja, između ostalog, pokazuju visoku razinu religioznosti u općem smislu te visoku razinu religijske samoidentifikacije, relativnu stabilnost institucionalne religijske prakse, uz primjetan određeni pad vjerovanja u temeljne religijske istine, te istovremeno relativno stabilnu prisutnost individualizirane religioznosti i „alternativne religioznosti“ (Marinović Jerolimov 2005.; Črpić, Zrinščak, 2010.; Marinović Jerolimov, Jokić, 2010.; Nikodem, Zrinščak, 2012.). U skladu s općom pretpostavkom te naznačenim smjerom analize u radu postavljamo sljedeće radne hipoteze:

H1. Studenti Hrvatskog katoličkog sveučilišta skloniji su kršćanskoj religioznosti ${ }^{7}$ od studenata Sveučilišta u Zagrebu.

Kako je već navedeno, hipotezu temeljimo na specifičnim razlikama misije, vizije i sustava vrijednosti navedenih sveučilišta.

H2. Studentice su sklonije kršćanskoj religioznosti od studenata na svim ispitivanim dimenzijama.

6 Pod osnovnim sociodemografskim karakteristikama i političkim orijentacijama ispitanika u ovom radu podrazumijevamo sljedeće: 1 . Spol („1 = muški, 2 = ženski“); 2. Godina studija (1 - 6); 3. Veličina mjesta života („1. Manje od 2000 stanovnika, 2. Od 2000 do 5000 stanovnika, 3. Od 5000 do 10.000 stanovnika, 4. Od 10.000 do 20.000 stanovnika, 5. Od 20.000 do 50.000 stanovnika, 6. Od 50.000 do 100.000 stanovnika, 7. Od 100.000 do 500.000 stanovnika, 8. 500.000 i više stanovnika“); 4. Procjena imovinskog stanja obitelji ispitanika („1. Puno lošije od većine drugih, 2. Nešto lošije od većine drugih, 3. Ni bolje ni lošije od većine drugih, 4. Nešto bolje od većine drugih, 5. Puno bolje od većine drugih“); 5. Stupanj obrazovanja roditelja (majke i oca) („1. Bez škole, 2. Nedovršena osnovna škola, 3. Osnovna škola, 4. Srednja škola u trajanju 3 godine, 5. Srednja škola u trajanju 4 godine, 6. Viša škola, 7. Fakultet, 8. Magistrij, doktorat"); 6. Političke orijentacije (skala od 1 do 7).

7 U radu koristimo pojam „kršćanske religioznosti“ u smislu sklonosti „kršćanskom vjerovanju“, religijske samoidentifikacije u smislu „religioznosti u skladu s crkvenim učenjem“ te institucionalne religijske prakse u smislu tjednih pohađanja religijskih obreda. S obzirom na to da u istraživanju nažalost nemamo pitanje o konfesionalnoj pripadnosti, zbog ograničene mogućnosti broja pitanja u upitniku gdje religija nije osnovna tema, korištenje tog pojma ne podrazumijeva iskazanu pripadnost određenoj vjerskoj zajednici, ili zajednicama, već sklonost ispitanih studenata jednom određenom tipu religioznosti. Pojam „kršćanske religioznosti“ koristimo i zbog toga što mjerni instrument za sustave vjerovanja sadrži i čestice koje sadržajno obuhvaćaju jedan tip nekršćanske religioznosti. 
Hipotezu temeljimo na rezultatima dosadašnjih empirijskih istraživanja, koji pokazuju da su žene uglavnom sklonije religioznosti od muškaraca (Nikodem 2004., 2011.; Marinović Jerolimov 2005.; Črpić, Zrinščak, 2010.). Pritom je nužan oprez jer komparativna analiza rezultata dobivenih u projektu EVS pokazuje određene promjene sociodemografskog profila vjernika u smislu smanjenja udjela žena i povećanja udjela muškaraca (Črpić, Zrinščak, 2010.:22).

H3. Kršćanska religioznost ispitanih studenata bit će snažno povezana s njihovim političkim orijentacijama.

Treću hipotezu temeljimo na teorijskim pretpostavkama o procesima politizacije religije i religizacije politike, koji su posebice izraženi u hrvatskom društvu (Vrcan, 1999.:52), ali i na rezultatima dosadašnjih empirijskih istraživanja, koja pokazuju povezanost religioznosti i političkih orijentacija (Nikodem, 2011.).

\subsection{Metode}

U analizi podataka na koje se oslanjamo koristimo deskriptivne postupke te hi-kvadrat test, korelacijsku analizu (bivarijatna korelacija, Pearsonov koeficijent), analizu varijance, faktorsku analizu i multiplu regresijsku analizu, u sklopu koje se kriterijske varijable (dimenzije religioznosti) analiziraju s obzirom na navedeni prediktorski sklop. Podaci su obrađeni u programskom paketu IBM SPSS 25.

\section{Religijska samoidentifikacija}

Pitanje religijske samoidentifikacije, ili religioznosti u užem smislu, mjereno je instrumentom koji osim razlikovanja onih koji se smatraju religioznima, nesigurnima, nereligioznima ili protivnicima vjere sadrži i razlikovanje unutar onih ispitanika koji se smatraju „religioznima“, i to na „religiozne u skladu s crkvenim učenjem“ i „religiozne na svoj način“.

Tablica 2.

Koja od sljedećih izjava najbolje opisuje Vas osobno?

\begin{tabular}{|l|c|c|}
\hline & N & $\%$ \\
\hline Religiozan sam u skladu s crkvenim učenjem & 297 & 23,4 \\
\hline Religiozan sam na svoj način & 570 & 44,9 \\
\hline Nisam siguran jesam li religiozan ili nisam & 110 & 8,7 \\
\hline Nisam religiozan & 208 & 16,4 \\
\hline Protivnik sam vjere & 61 & 4,8 \\
\hline Bez odgovora & 24 & 1,9 \\
\hline
\end{tabular}

Većina ispitanih studenata smatra se religioznima (68,3 posto), dok se oko petine ispitanih studenata smatra nereligioznima ili protivnicima vjere. Dvije trećine onih koji se smatraju religioznima smatraju se „religioznima na svoj način“. Usporedba dobivenih rezultata s rezultatima empirijskih istraživanja koja su u posljednjih dvadesetak godina provedena na reprezentativnim uzorcima $s$ istim instrumentom po- 
kazuje da je među zagrebačkim studentima u odnosu na opću populaciju Hrvatske manje religioznih u općem smislu.

Tablica 3.

Religijska samoidentifikacija u hrvatskom društvu od 1997. do 2010. godine.

\begin{tabular}{|l|c|c|c|}
\hline \multirow{2}{*}{} & \multicolumn{3}{|c|}{$\%$} \\
\cline { 2 - 4 } & 1997. & 2004. & 2010. \\
\hline Religiozan/na sam u skladu s crkvenim učenjem & 31,2 & 45,4 & 47,2 \\
\hline Religiozan/na sam na svoj način & 53,3 & 42,2 & 41,6 \\
\hline Nisam siguran/na jesam li religiozan/na ili ne & 7,5 & 4,5 & 3,8 \\
\hline Nisam religiozan/a & 5,6 & 6,5 & 7,1 \\
\hline Protivnik/ca sam vjere & 2,4 & 1,1 & 0,3 \\
\hline
\end{tabular}

Izvor: Nikodem, 2011.

Također, među zagrebačkim studentima manje je onih koji se smatraju „religioznima u skladu s crkvenim učenjem“, a nešto više onih koji se smatraju „religioznima na svoj način“ te više onih koji su nesigurni po pitanju vlastite religioznosti, koji se smatraju nereligioznima i protivnicima vjere.

Rezultati prijašnjih empirijskih istraživanja na uzorcima mladih pokazuju određeni porast religijske samoidentifikacije unutar kohorte mladih. Tako je 1999. godine bilo 66,4 posto religioznih među mladima u Hrvatskoj (Marinović Jerolimov, 2002.:84), dok ih je 2004. godine bilo 73,1 posto (Ilišin, Radin, 2007.:296). S druge strane, rezultati istraživanja provedenih na studentima pokazuju blagi pad u tom smislu jer je 2010. godine bilo 57,3 posto religioznih među studentima (Ilišin, 2014.:478), a 2015. godine 52,3 posto (Boneta, 2016.:284). Rezultati našeg istraživanja predstavljaju jasan odmak od naznačenog trenda, a jedan je od razloga to što nešto više od trećine našeg prigodnog uzorka zagrebačkih studenata čine studenti Hrvatskog katoličkog sveučilišta, za koje smo i pretpostavili višu razinu religioznosti od studenata Sveučilišta u Zagrebu. ${ }^{8}$ Kraći pregled pitanja religijske samoidentifikacije prema pripadnosti fakultetu ili sveučilištu pokazuje da je na HKS-u najviše onih koji se smatraju religioznima (83,7 posto), dok ih je najmanje na FFZG-u (54,5 posto).

Tablica 4.

Religijska samoidentifikacija prema pripadnosti sveučilištu/fakultetu.

\begin{tabular}{|l|c|c|c|c|}
\hline \multicolumn{1}{|c|}{$\%$} & FFZG & HKS & FSB & MEF \\
\hline Religiozan sam u skladu s crkvenim učenjem & 10,2 & 35,9 & 18,3 & 17,8 \\
\hline Religiozan sam na svoj način & 44,3 & 47,8 & 38,8 & 45,6 \\
\hline Nisam siguran jesam li religiozan ili nisam & 13,5 & 7,0 & 7,9 & 8,1 \\
\hline Nisam religiozan & 25,0 & 7,2 & 21,3 & 20,5 \\
\hline Protivnik sam vjere & 6,1 & 1,8 & 6,7 & 7,0 \\
\hline Bez odgovora & 0,8 & 0,2 & 7,1 & 1,0 \\
\hline
\end{tabular}

8 U nastavku teksta koristit ćemo skraćenice HKS I SVZG za sveučilišta, te FFZG, MEF I FSB za fakultete. 
Među ispitanim studentima prevladava individualizirana religioznost (,religioznost na svoj način“) u odnosu na institucionaliziranu religioznost (,religioznost u skladu s crkvenim učenjem“). Na uključenim sastavnicama SVZG-a podjednak je postotak studenata koji se smatraju nereligioznima i protivnicima vjere, dok je taj postotak znatno niži na HKS-u. Navedene razlike jasnije su kada usporedimo dobivene rezultate na razini sveučilišta, gdje se religioznima smatra 58,7 posto studenata SVZG-a naspram već navedenih 83,7 posto religioznih na HKS-u.

Tablica 5.

Religijska samoidentifikacija na SVZG-u i HKS-u. ${ }^{?}$

\begin{tabular}{|l|c|c|}
\hline \multicolumn{1}{|c|}{$\%$} & SVZG & HKS \\
\hline Religiozan sam u skladu s crkvenim učenjem & 15,6 & 35,9 \\
\hline Religiozan sam na svoj način & 43,1 & 47,8 \\
\hline Nisam siguran jesam li religiozan ili nisam & 9,7 & 7,0 \\
\hline Nisam religiozan & 22,1 & 7,2 \\
\hline Protivnik sam vjere & 6,6 & 1,8 \\
\hline Bez odgovora & 2,8 & 0,2 \\
\hline
\end{tabular}

Nesigurnih u vlastitu religijsku identifikaciju, nereligioznih i protivnika vjere na SVZG-u je 38,4 posto, dok je taj postotak na HKS-u znatno manji (16,0 posto).

U nastavku analiziramo pitanje religijske samoidentifikacije s obzirom na osnovne sociodemografske karakteristike i političke orijentacije ispitanih studenata. ${ }^{10}$

9 Rezultati hi-kvadrat testa pokazuju statistički značajnu razliku $\left(\chi^{2}=111,476\right.$; df $=4$; p < 0,001). Studenti HKS-a skloniji su smatrati se „religioznima u skladu s crkvenim učenjem“, za razliku od studenata SVZG-a, koji su skloniji smatrati se religijski nesigurnima, nereligioznima ili protivnicima vjere.

10 Analiza provedena regresijskom analizom gdje je pitanje religijske samoidentifikacije postavljeno kao kriterijska varijabla (skala rekodirana tako da je $1=$, protivnik sam vjere“...5 = „religiozan sam u skladu s crkvenim učenjem“, iz skale izbačeno „bez odgovora“). Prediktorski sklop čine sljedeće varijable: 1. spol (skala 1 = „muški“, 2 = „ženski“), 2. godina studija (od 1 do 6), 3. $i$ 4. stupanj obrazovanja roditelja (majke i oca - skala 1 = „bez škole“, 2 = „nedovršena osnovna škola“, 3 = „osnovna škola“, 4 = „srednja škola u trajanju od 3 godine“, 5 = „srednja škola u trajanju od 4 godine“, 6 = „viša škola“, 7 = „fakultet“, 8 = „magisterij, doktorat"), 5. procjena imovinskog stanja obitelji (skala od $1=$ „puno lošije od većine drugih“ do 5 = „puno bolje od većine drugih“), 6. veličina mjesta u kojem su proveli većinu svog života (skala od 1 = „manje od 2000“ do $8=, 500.000$ i više“), 7. političke orijentacije (skala od 1 do 7 rekodirana na način da je 1, 2 = „lijevo“, 3, 4 i 5 = „centar“, a 6, 7 = „desno“). 
Tablica 6.

Religijska samoidentifikacija s obzirom na sociodemografske karakteristike i političke orijentacije.

\begin{tabular}{|c|c|c|c|c|c|}
\hline & & \multirow{2}{*}{$\begin{array}{c}\begin{array}{c}\text { standardizirani } \\
\text { koeficijenti }\end{array} \\
\text { beta }\end{array}$} & \multirow{2}{*}{$p$} & \multicolumn{2}{|c|}{ korelacije } \\
\hline & & & & direktne & parcijalne \\
\hline \multirow{3}{*}{$\begin{array}{c}\text { Religijska } \\
\text { samoidentifikacija }\end{array}$} & $\begin{array}{l}\text { Političke } \\
\text { orijentacije }\end{array}$ & .513 & $<.001$ & .511 & .511 \\
\hline & Spol & .173 & $<.001$ & 162 & .172 \\
\hline & $\begin{array}{l}\text { Stupanj } \\
\text { obrazovanja majke }\end{array}$ & -.076 & $<.002$ & -.125 & -.076 \\
\hline & \multicolumn{5}{|l|}{$R^{2}=.300$} \\
\hline
\end{tabular}

Rezultati regresijske analize pokazuju da prediktorski sklop tumači 30,0 posto kriterijske varijable. Religijska samoidentifikacija statistički je značajno povezana s trima od ukupno sedam odabranih prediktora. Najvažniji su prediktor političke orijentacije, a zatim spol i sa znatno nižom značajnošću stupanj obrazovanja majke ispitanika. Dakle studentice politički desno orijentirane i čija majka ima niži stupanj obrazovanja sklonije su smatrati se religioznima.

Slični rezultati, iako na drugačijem instrumentu mjerenja religijske samoidentifikacije, dobiveni su i 2015. godine u istraživanju religioznosti riječkih studenata, gdje se između ostalog navodi da su studentice, iz manjih mjesta i čija majka ima niži stupanj obrazovanja sklonije smatrati se religioznima (Boneta, 2016.:285). Komparativna analiza rezultata dobivenih 1999. i 2008. godine na projektu EVS pokazuje porast religioznosti kod onih koji su rođeni nakon 1976. godine i pad religioznosti kod ispitanika rođenih prije 1945. godine te da su religioznosti sklonije žene s nižim stupnjem obrazovanja (Črpić, Zrinščak, 2010.:10).

\section{Institucionalna religijska praksa}

Pitanje institucionalne religijske prakse mjereno je standardiziranim instrumentom za obrednu dimenziju religioznosti. Rezultati pokazuju da oko trećine ispitanih studenata tjedno pohađa religijske obrede, odnosno odlazi u crkvu na misu. Nešto više od trećine ih pohađa religijske obrede jednom ili više puta godišnje, dok njih 12,8 posto uopće ne pohađa religijske obrede. 
Tablica 7.

Ako se izuzmu izuzetne prilike kao vjenčanja, pogrebi, krštenja i slično, koliko često pohađate religijske obrede? ${ }^{11}$

\begin{tabular}{|l|c|}
\hline & $\%$ \\
\hline Nikada & 12,8 \\
\hline Jednom u nekoliko godina & 11,3 \\
\hline Više puta godišnje (za velikih blagdana) & 25,1 \\
\hline Jednom mjesečno & 9,2 \\
\hline Jednom tjedno & 26,1 \\
\hline Gotovo svakodnevno & 4,9 \\
\hline Nisam vjernik & 8,7 \\
\hline Bez odgovora & 1,9 \\
\hline
\end{tabular}

Usporedba tih rezultata s rezultatima za opću populaciju u Hrvatskoj u posljednjih dvadesetak godina pokazuje da je među ispitanim studentima viši postotak „vjernika praktikanata" nego u općoj populaciji.

Tablica 8.

Institucionalna religijska praksa u hrvatskom društvu od 1997. do 2010. godine.

\begin{tabular}{|l|c|c|c|c|c|}
\hline \multirow{2}{*}{} & \multicolumn{4}{|c|}{$\%$} & \multicolumn{2}{c|}{} \\
\cline { 2 - 6 } & 1997. & 1999. & 2004. & 2008. & 2010. \\
\hline Nikada & 14,1 & 10,4 & 6,3 & 15,7 & 8,5 \\
\hline Jednom u nekoliko godina & 14,0 & 9,7 & 9,7 & 15,1 & 12,9 \\
\hline Više puta godišnje (za velikih blagdana) & 29,7 & 26,9 & 38,5 & 25,2 & 40,9 \\
\hline Mjesečno & 17,0 & 21,1 & 16,6 & 16,2 & 12,8 \\
\hline Tjedno & 25,0 & 31,4 & 24,5 & 26,4 & 22,9 \\
\hline
\end{tabular}

Izvor: Nikodem, 2011.

U većini ostalih kategorija dobiveni rezultati na ovom prigodnom uzorku zagrebačkih studenata uglavnom su slični rezultatima koji su dobiveni za opću populaciju. Ispitani studenti imaju nešto niži postotak mjesečnih i povremenih odlazaka u crkvu na misu.

Rezultati prethodnih empirijskih istraživanja provedenih na uzorcima mladih pokazuju da je 1986. godine 13,0 posto mladih odlazilo tjedno na misu, a 27,0 posto „praktikanata“ među mladima bilo je 1999. godine (Marinović Jerolimov, 2002.:100). Nadalje, rezultati na drugačijoj skali pokazuju da je 2004. godine 21,6 posto mladih „Često“ odlazilo u crkvu (Ilišin, Radin, 2007.:327), a 2012. godine takvih je 25,7 posto (Ilišin i drugi, 2013.:158). Rezultati istraživanja provedenih na uzorku studenata pokazuju da 2010. godine „često“ odlazi u crkvu 21,1 posto (Ilišin, 2014.:479), a 2015. godine 21,9 posto (Boneta, 2016.:280). I na ovom pitanju rezultati našeg istraživanja pokazuju više postotke za „vjernike praktikante“ od rezultata drugih istraživanja.

11 Upitnik iz 2005. godine nije sadržavao ni ovo pitanje. 
Kada usporedimo pitanje institucionalne religijske prakse prema pripadnosti fakultetu/sveučilištu, vidljive su velike razlike, posebice između studenata HKS-a i FFZG-a.

Tablica 9.

Institucionalna religijska praksa prema pripadnosti fakultetu/sveučilištu.

\begin{tabular}{|l|c|c|c|c|}
\hline \multicolumn{1}{|c|}{$\%$} & FFZG & HKS & FSB & MEF \\
\hline Nikada & 22,1 & 6,4 & 13,8 & 14,8 \\
\hline Jednom u nekoliko godina & 13,5 & 9,2 & 10,4 & 13,8 \\
\hline Više puta godišnje (za velikih blagdana) & 24,2 & 25,7 & 24,6 & 25,5 \\
\hline Jednom mjesečno & 6,1 & 11,9 & 8,3 & 8,1 \\
\hline Jednom tjedno & 14,8 & 34,1 & 24,2 & 24,2 \\
\hline Gotovo svakodnevno & 2,0 & 9,0 & 3,3 & 1,7 \\
\hline Nisam vjernik & 16,4 & 3,5 & 8,3 & 11,4 \\
\hline Bez odgovora & 0,8 & 0,2 & 7,1 & 0,7 \\
\hline
\end{tabular}

Nešto manje od polovice (43,1 posto) ispitanih studenata HKS-a odlazi u crkvu na misu jednom ili više puta tjedno, za razliku od studenata FSB-a i MEF-a, gdje ih oko četvrtine tjedno pohađa religijske obrede i studenata FFZG-a, gdje to čini oko 17 posto. Povremeno pohađanje religijskih obreda, odnosno prigodno prema većim blagdanima podjednako je zastupljeno kako kod studenata HKS-a tako i kod studenata triju sastavnica SVZG-a. Na FFZG-u ima najviše onih koji uopće ne pohađaju religijske obrede (oko petine ispitanih studenata), dok je takvih najmanje na HKS-u (6,4 posto).

Tablica 10.

Institucionalna religijska praksa na SVZG-u i HKS-u.

\begin{tabular}{|l|c|c|}
\hline \multicolumn{1}{|c|}{$\%$} & SVZG & HKS \\
\hline Nikada & 16,8 & 6,4 \\
\hline Jednom u nekoliko godina & 12,7 & 9,2 \\
\hline Više puta godišnje (za velikih blagdana) & 24,8 & 25,7 \\
\hline Jednom mjesečno & 7,5 & 11,9 \\
\hline Jednom tjedno & 21,2 & 34,1 \\
\hline Gotovo svakodnevno & 2,3 & 9,0 \\
\hline Nisam vjernik & 12,0 & 3,5 \\
\hline Bez odgovora & 2,7 & 0,2 \\
\hline
\end{tabular}

Usporedba tog pitanja na razini sveučilišta pokazuje da je na HKS-u gotovo dvostruko više „vjernika praktikanata“ (43,1 posto) nego na SVZG-u (23,5 posto). ${ }^{12}$ Razina prigodnih pohađanja religijskih obreda slična je na obama sveučilištima, dok je na SVZG-u znatno više onih koji uopće ne pohađaju religijske obrede.

12 Na pitanju institucionalne religijske prakse skala rekodirana tako da je 1 = „Nikada“; 2 = „Povremeno“; 3 = „Mjesečno“, a 4 = „Tjedno“. Rezultati hi-kvadrat testa pokazuju statistički značajnu razliku $\left(\chi^{2}=63,549\right.$; $\left.\mathrm{df}=3 ; \mathrm{p}<0,001\right)$. Studenti HKS-a skloniji su tjednim i mjesečnim odlascima u crkvu na misu, dok su studenti SVZG-a skloniji uopće ne pohađati religijske obrede ili to činiti povremeno. 
U daljnjoj analizi pitanje institucionalne religijske prakse analiziramo s obzirom na osnovne sociodemografske karakteristike i političke orijentacije ispitanika.

Tablica 11.

Institucionalna religijska praksa s obzirom na sociodemografske karakteristike i političke orijentacije.

\begin{tabular}{|l|l|c|c|c|c|}
\hline & & $\begin{array}{c}\text { standardizirani } \\
\text { koeficijenti }\end{array}$ & \multirow{2}{*}{$p$} & \multicolumn{2}{|c|}{ korelacije } \\
\cline { 5 - 6 } & & beta & & direktne & parcijalne \\
\cline { 3 - 6 } & & .511 & $<.001$ & .508 & .510 \\
\hline \multirow{2}{*}{$\begin{array}{c}\text { Institucionalna } \\
\text { religijska praksa }\end{array}$} & Političke orijentacije & .105 & $<.001$ & .105 & .092 \\
\cline { 2 - 6 } & Spol & $\mathrm{R}^{2}=.276$ & & & \\
\hline
\end{tabular}

Rezultati regresijske analize pokazuju da navedeni prediktorski sklop tumači 27,6 posto kriterijske varijable uz dva značajna prediktora - političke orijentacije i spol. Studentice politički desno orijentirane sklonije su češće pohađati religijske obrede.

Rezultati za riječke studente pokazuju da su tjednim pohađanjima religijskih obreda sklonije studentice, iz manjih mjesta i čija majka ima niži stupanj obrazovanja (Boneta, 2016.:280-281). Komparativna analiza rezultata projekta EVS pak pokazuje da između 1999. i 2008. godine dolazi do pada u tjednom pohađanju religijskih obreda i porasta onih koji uopće ne odlaze na religijske obrede. Nadalje, povećao se broj muškaraca koji uopće ne odlaze na religijske obrede, a smanjio se broj žena koje ih pohađaju tjedno. Unutar ispitanika s višim stupnjem obrazovanja stabilizirao se broj onih koji odlaze na religijske obrede, a smanjio se kod ispitanika sa srednjim stupnjem obrazovanja. Također, kod najmlađeg dijela populacije stabilizirao se broj onih koji redovito odlaze na religijske obrede, dok se taj broj smanjio kod najstarijeg dijela populacije (Črpić, Zrinščak, 2010.:14).

\section{Sustavi vjerovanja}

Vjerovanje kao jedna od ključnih dimenzija religioznosti ispitivano je instrumentom koji sadrži dvadeset čestica, a koje sadržajno obuhvaćaju ključne postavke vjerovanja u kršćanstvu, različite tipove praznovjerja i elemente vjerovanja koje smo u prvom valu ovog istraživanja nazvali „kozmičkom ireligijom“ (Nikodem, 2005.:183) i koji pripadaju nekršćanskoj duhovnosti.

Usporedba dobivenih rezultata prvog i drugog vala ovog istraživanja pokazuje opadanje vjerovanja u osnovne postavke kršćanstva, relativnu stabilnost praznovjerja i blagi porast vjerovanja koja pripadaju „kozmičkoj ireligiji“.

Na svim elementima kršćanskog vjerovanja dobiveno je opadanje, posebice se to odnosi na ključni dio kršćanskog vjerovanja da „postoji Bog kao osoba“, u što je 2005. godine vjeru iskazivalo 46,7 posto ispitanih studenata, a 2017. godine njih 36,2 posto. Osim toga zamjetan je i pad vjerovanja da je „Biblija doista riječ Božja“ (s 51,6 posto na 42,0 posto), da će „na kraju vremena Krist ponovo doći na Zemlju“ (s 46,5 
posto na 37,8 posto) i da je „Crkva stvorena od Boga“ (s 48,2 posto na 41,4 posto). Ostali dijelovi kršćanskog vjerovanja koji su bili ispitivani bilježe manji pad. Tako je 2005. godine 51,4 posto ispitanih studenata vjerovalo da „postoje raj i pakao“, naspram 46,5 posto u 2017. godini, a da „čovjek ima besmrtnu dušu“ 2005. godine vjerovalo je 59,8 posto ispitanih studenata, naspram njih 56,4 posto 2017 . godine.

Najveći porast vjerovanja u navedenom razdoblju dobiven je na tvrdnji „ne postoji Bog, ali postoji nešto nadzemaljsko“ (s 11,2 posto na 18,8 posto).

Tablica 12.

U što od navedenog Vi osobno vjerujete? ${ }^{13}$

\begin{tabular}{|c|c|c|c|c|c|c|}
\hline \multirow[t]{2}{*}{$\%$} & \multicolumn{3}{|c|}{2005.} & \multicolumn{3}{|c|}{2017.} \\
\hline & 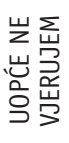 & 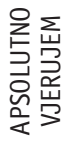 & 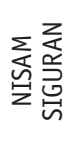 & $\begin{array}{l}\text { 岁岀 } \\
\text { 岁总 } \\
\text { 옹 }\end{array}$ & 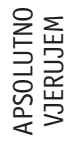 & 点京 \\
\hline Postoji Bog kao osoba & 26,0 & 46,7 & 27,2 & 36,2 & 36,2 & 26,0 \\
\hline Čovjek ima besmrtnu dušu & 13,0 & 59,8 & 27,2 & 14,5 & 56,4 & 27,9 \\
\hline Biblija je doista riječ Božja & 21,3 & 51,6 & 27,0 & 34,3 & 42,0 & 22,8 \\
\hline Crkva je stvorena od Boga & 28,0 & 48,2 & 23,8 & 37,6 & 41,4 & 19,8 \\
\hline Na kraju vremena Krist će ponovo doći na Zemlju & 22,8 & 46,5 & 30,7 & 35,1 & 37,8 & 25,7 \\
\hline Postoje raj i pakao & 22,2 & 51,4 & 26,4 & 29,0 & 46,5 & 23,4 \\
\hline U duhove & 41,9 & 27,8 & 30,3 & 47,1 & 24,1 & 27,2 \\
\hline U reinkarnaciju, tj. ponovno rađanje na ovom svijetu & 58,1 & 9,8 & 32,1 & 57,2 & 11,0 & 30,6 \\
\hline Horoskop točno predviđa budućnost & 85,0 & 0,8 & 14,2 & 88,3 & 2,0 & 8,6 \\
\hline Postoje ljudi koji mogu baciti urok ili prokletstvo & 56,9 & 14,4 & 28,7 & 63,5 & 13,6 & 21,7 \\
\hline Neke osobe mogu stupiti u kontakt s mrtvima & 54,5 & 12,4 & 33,1 & 60,7 & 10,8 & 27,4 \\
\hline 13 je nesretan broj & 91,3 & 1,4 & 7,3 & 92,8 & 1,3 & 5,0 \\
\hline U radiesteziju i bioenergiju & 39,8 & 17,7 & 42,5 & 51,0 & 12,2 & 35,6 \\
\hline Svijetom vlada kozmička inteligencija & 52,2 & 7,3 & 40,4 & 51,7 & 8,6 & 38,3 \\
\hline Ne postoji Bog, ali postoji nešto nadzemaljsko & 58,9 & 11,2 & 29,9 & 51,0 & 18,8 & 28,8 \\
\hline $\begin{array}{l}\text { Postoji mnoštvo beskrajnih svemira kojima upravljaju } \\
\text { bića superiorne inteligencije }\end{array}$ & 50,0 & 7,3 & 42,7 & 50,2 & 9,8 & 38,8 \\
\hline $\begin{array}{l}\text { Ljudi žive u svemiru koji je umjetna tvorevina } \\
\text { superiornih bića }\end{array}$ & 64,2 & 3,0 & 32,7 & 66,6 & 3,1 & 29,0 \\
\hline $\begin{array}{l}\text { Čovjek nije stvoren na sliku Božju, već je proizvod } \\
\text { kozmičke slučajnosti }\end{array}$ & 54,1 & 17,3 & 28,7 & 49,1 & 21,9 & 27,9 \\
\hline $\begin{array}{l}\text { Osnovno Božje svojstvo je periodična promjenjivost } \\
\text { Dobra i Zla }\end{array}$ & 54,5 & 9,1 & 36,4 & 58,5 & 7,7 & 32,7 \\
\hline Ne postoji jedan Bog, već postoje mnoga božanstva & 77,4 & 2,6 & 19,9 & 75,6 & 3,5 & 19,8 \\
\hline
\end{tabular}

13 Manji dio ispitanih studenata na pojedinim elementima vjerovanja nije zaokružio ni jedan od ponuđenih odgovora ili je zaokružio više od jednog ponuđenog odgovora, te su takvi stavljeni u „missing vrijednosti“, što je posljedično dovelo do toga da je na pojedinim elementima vjerovanja ukupan postotak odgovora nešto manji od sto posto. 
Djelomična usporedba dobivenih rezultata s rezultatima istraživanja koja su provedena na reprezentativnim uzorcima za cjelokupnu populaciju pokazuje slične trendove. Naime rezultati projekta EVS za 1999. i 2008. godinu jasno pokazuju opadanje vjerovanja u temeljne religijske istine kršćanstva. Tako se u navedenom razdoblju vjerovanje u Boga smanjilo s 91,4 posto na 85,8 posto, vjerovanje u život poslije smrti smanjilo se s 59,5 posto na 50,1 posto, a vjerovanje u pakao i raj smanjilo se s 48,9 posto na 39,8 posto, odnosno s 55,8 posto na 52,3 posto (Rimac, 2014.:334).

Rezultati prethodnih empirijskih istraživanja na uzorcima mladih i studenata pokazuju da je 1999. godine 77,2 posto mladih vjerovalo da Bog postoji (Ilišin, Radin, 2002.:347), a trinaest godina kasnije vjerovanje u Boga na gotovo je istoj razini (78,7 posto) (Ilišin i drugi, 2013.:158). No 2015. godine Boneta je u istraživanju na uzorku riječkih studenata dobio 53,7 posto onih koji vjeruju u Boga (Boneta, 2016.:275). Da postoji raj i pakao 1999. godine vjerovalo je 50,6 posto mladih (Ilišin, Radin, 2002.:347), a 2012. godine 62,3 posto mladih (Ilišin i drugi, 2013.:158). Među riječkim studentima taj je postotak znatno niži (28,5 posto) (Boneta, 2016.:275).

Komparativni pregled rezultata na sustavu vjerovanja prema godini istraživanja i pripadnosti fakultetu, odnosno sveučilištu jasno pokazuje pad vjerovanja u neke od ključnih istina kršćanstva. U navedenom razdoblju od 2005. godine do 2017. godine vjerovanje da „postoji Bog kao osoba“ u padu je na svim trima fakultetima čiji su studenti sudjelovali u obama valovima istraživanja i gdje su time i usporedbe moguće. Najveći pad vjerovanja da „postoji Bog kao osoba“ je na FFZG-u (19 posto), dok je taj pad podjednak na MEF-u (14 posto) i na FSB-u (13 posto). Vjerovanje „da čovjek ima besmrtnu dušu" također je u najvećem padu na FFZG-u (15 posto), a na ostalim dvama fakultetima zagrebačkog sveučilišta u podjednakom je padu (oko 6 posto).

Tablica 13.

Vjerovanje prema godini istraživanja i pripadnosti fakultetu/sveučilištu.

\begin{tabular}{|l|c|c|c|c|c|c|}
\hline \multicolumn{1}{|c|}{$\%$} & \multicolumn{3}{c|}{2005.} & \multicolumn{3}{c|}{2017.} \\
\hline & FFZG & FSB & MEF & FFZG & FSB & MEF \\
\hline Postoji Bog kao osoba & 35,8 & 43,5 & 41,5 & 16,8 & 30,8 & 27,2 \\
\hline Čovjek ima besmrtnu dušu & 54,0 & 52,9 & 52,3 & 38,9 & 46,3 & 45,6 \\
\hline Biblija je doista riječ Božja & 34,3 & 52,2 & 47,7 & 22,1 & 36,3 & 34,6 \\
\hline Crkva je stvorena od Boga & 27,0 & 47,1 & 43,1 & 20,1 & 37,1 & 31,5 \\
\hline $\begin{array}{l}\text { Na kraju vremena Krist će ponovo doći } \\
\text { na Zemlju }\end{array}$ & 32,1 & 40,6 & 46,2 & 17,6 & 32,5 & 29,9 \\
\hline Postoje raj i pakao & 35,0 & 50,7 & 50,8 & 28,7 & 40,4 & 36,2 \\
\hline U duhove & 18,2 & 22,5 & 26,2 & 22,1 & 17,5 & 15,4 \\
\hline
\end{tabular}




\begin{tabular}{|l|c|c|c|c|c|c|}
\hline \multicolumn{1}{|c|}{$\%$} & \multicolumn{3}{|c|}{2005.} & \multicolumn{3}{c|}{2017.} \\
\hline & FFZG & FSB & MEF & FFZG & FSB & MEF \\
\hline $\begin{array}{l}\text { U reinkarnaciju, tj. ponovno rađanje na } \\
\text { Ovom svijetu }\end{array}$ & 11,7 & 13,0 & 3,1 & 16,0 & 11,3 & 7,4 \\
\hline Horoskop točno predviđa budućnost & 1,5 & - & 1,5 & 2,0 & 3,3 & 1,3 \\
\hline $\begin{array}{l}\text { Postoje ljudi koji mogu baciti urok ili } \\
\text { prokletstvo }\end{array}$ & 14,6 & 11,6 & 10,8 & 13,5 & 7,9 & 4,0 \\
\hline $\begin{array}{l}\text { Neke osobe mogu stupiti u kontakt s } \\
\text { mrtvima }\end{array}$ & 10,2 & 9,4 & 10,8 & 12,3 & 5,8 & 5,0 \\
\hline \begin{tabular}{l} 
13 je nesretan broj \\
\hline U radiesteziju i bioenergiju
\end{tabular} & 1,5 & 0,7 & 3,1 & - & 3,3 & 1,3 \\
\hline $\begin{array}{l}\text { Svijetom vlada kozmička inteligencija } \\
\text { Ne postoji Bog, ali postoji nešto }\end{array}$ & 7,3 & 8,0 & 9,2 & 11,5 & 8,3 & 8,4 \\
\hline $\begin{array}{l}\text { nadzemaljsko } \\
\text { Postoji mnoštvo beskrajnih svemira kojima bića superiorne inteligencije }\end{array}$ & 2,2 & 15,2 & 9,2 & 9,4 & 14,2 & 7,4 \\
\hline $\begin{array}{l}\text { Ljudi žive u svemiru koji je umjetna } \\
\text { tvorevina superiornih bića }\end{array}$ & 0,7 & 5,1 & 4,6 & 1,2 & 7,1 & 3,7 \\
\hline $\begin{array}{l}\text { Čovjek nije stvoren na sliku Božju, već je } \\
\text { proizvod kozmičke slučajnosti }\end{array}$ & 22,6 & 17,4 & 15,4 & 32,8 & 25,8 & 29,5 \\
\hline $\begin{array}{l}\text { Osnovno Božje svojstvo je periodična } \\
\text { promjenjivost Dobra i Zla }\end{array}$ & 10,2 & 11,6 & 10,8 & 6,6 & 10,0 & 7,0 \\
\hline $\begin{array}{l}\text { Ne postoji jedan Bog, već postoje mnoga } \\
\text { božanstva }\end{array}$ & 2,9 & 2,9 & 3,1 & 5,3 & 3,8 & 3,4 \\
\hline
\end{tabular}

Nadalje, na MEF-u je najveći pad vjerovanja da će „na kraju vremena Krist ponovo doći na Zemlju“ (16 posto) te da "postoje raj i pakao“ (14 posto). Najveći pad vjerovanja na FSB-u je u vjerovanje da je „Biblija doista riječ Božja“ (16 posto). S druge strane, vidljiv je porast vjerovanja da „ne postoji Bog, ali postoji nešto nadzemaljsko“, na FFZG-u za 13 posto, na MEF-u za 11 posto i na FSB-u za 7 posto. Također, u navedenom razdoblju došlo je do porasta vjerovanja da „čovjek nije stvoren na sliku Božju, već je proizvod kozmičke slučajnosti“" (MEF za 14 posto, FFZG za 10 posto i FSB za 8 posto). Dobiveni rezultati na toj osnovnoj razini usporedbe ukazuju na to da je pad vjerovanja u neke od osnovnih istina kršćanstva popraćen porastom jedne nekršćanske duhovnosti.

U nastavku dajemo pregled vjerovanja prema pripadnosti sveučilištu. Vidljiva je jasna razlika između studenata HKS-a i SVZG-a, gdje studenti HKS-a u znatno višem postotku iskazuju vjerovanje u neke od ključnih istina kršćanstva, dok studenti SVZG-a u većem postotku iskazuju vjerovanje u neke elemente nekršćanske duhovnosti. 
Tablica 14.

Vjerovanje prema pripadnosti sveučilištu.

\begin{tabular}{|l|c|c|}
\hline \multicolumn{1}{|c|}{$\%$} & SVZG & HKS \\
\hline Postoji Bog kao osoba & 25,1 & 54,2 \\
\hline Čovjek ima besmrtnu dušu & 43,7 & 76,8 \\
\hline Biblija je doista riječ Božja & 31,2 & 59,3 \\
\hline Crkva je stvorena od Boga & 29,7 & 60,4 \\
\hline Na kraju vremena Krist će ponovo doći na Zemlju & 26,9 & 55,4 \\
\hline Postoje raj i pakao & 35,2 & 64,7 \\
\hline U duhove & 18,2 & 33,7 \\
\hline U reinkarnaciju, tj. ponovno rađanje na ovom svijetu & 11,3 & 10,7 \\
\hline Horoskop točno predviđa budućnost & 2,2 & 1,8 \\
\hline Postoje ljudi koji mogu baciti urok ili prokletstvo & 8,2 & 22,4 \\
\hline Neke osobe mogu stupiti u kontakt s mrtvima & 7,5 & 16,0 \\
\hline 13 je nesretan broj & 1,5 & 0,8 \\
\hline U radiesteziju i bioenergiju & 11,6 & 13,1 \\
\hline Svijetom vlada kozmička inteligencija & 9,3 & 7,4 \\
\hline Ne postoji Bog, ali postoji nešto nadzemaljsko & 22,3 & 13,3 \\
\hline Postoji mnoštvo beskrajnih svemira kojima upravljaju bića superiorne inteligencije & 10,1 & 9,4 \\
\hline Ljudi žive u svemiru koji je umjetna tvorevina superiornih bića & 4,0 & 1,8 \\
\hline Čovjek nije stvoren na sliku Božju, već je proizvod kozmičke slučajnosti & 29,4 & 9,9 \\
\hline Osnovno Božje svojstvo je periodična promjenjivost Dobra i Zla & 7,8 & 7,6 \\
\hline Ne postoji jedan Bog, već postoje mnoga božanstva & 4,1 & 2,7 \\
\hline
\end{tabular}

Nakon tog pregleda distribucije postotaka sustava vjerovanja prema pripadnosti sveučilištu na istim česticama proveli smo korelacijsku analizu (bivarijatna korelacija, Pearsonov koeficijent korelacije). Rezultati pokazuju da su studenti HKS-a skloniji vjerovanju u prvih šest tvrdnji, koje sadržajno obuhvaćaju temeljne religijske istine kršćanstva, no također i da su studenti HKS-a skloniji vjerovanju „u duhove“, „da postoje ljudi koji mogu baciti urok ili prokletstvo“ te da „neke osobe mogu stupiti u kontakt s mrtvima“.

Tablica 15.

Vjerovanje s obzirom na pripadnost sveučilištu (korelacijska analiza).

\begin{tabular}{|l|c|}
\hline & Sveučilište \\
\hline Postoji Bog kao osoba & $.314^{* *}$ \\
\hline Čovjek ima besmrtnu dušu & $.307^{* *}$ \\
\hline Biblija je doista riječ Božja & $.316^{* *}$ \\
\hline Crkva je stvorena od Boga & $.334^{* *}$ \\
\hline Na kraju vremena Krist će ponovo doći na Zemlju & $.337^{* *}$ \\
\hline Postoje raj i pakao & $.308^{* *}$ \\
\hline U duhove & $.209^{* *}$ \\
\hline U reinkarnaciju, tj. ponovno radanje na ovom svijetu & $-.063^{*}$ \\
\hline Horoskop točno predviđa budućnost & -.006 \\
\hline Postoje ljudi koji mogu baciti urok ili prokletstvo & $.227^{* *}$ \\
\hline Neke osobe mogu stupiti u kontakt s mrtvima & $.162^{* *}$ \\
\hline 13 je nesretan broj & -.041 \\
\hline U radiesteziju i bioenergiju & -.012 \\
\hline Svijetom vlada kozmička inteligencija & $-.058^{*}$ \\
\hline Ne postoji Bog, ali postoji nešto nadzemaljsko & $-.199^{* *}$ \\
\hline Postoji mnoštvo beskrajnih svemira kojima upravljaju bića superiorne inteligencije & $-.079^{* * *}$ \\
\hline Ljudi žive u svemiru koji je umjetna tvorevina superiornih bića & $-.119^{* *}$ \\
\hline Čovjek nije stvoren na sliku Božju, već je proizvod kozmičke slučajnosti & $-.310^{* * *}$ \\
\hline Osnovno Božje svojstvo je periodična promjenjivost Dobra i Zla & -.040 \\
\hline Ne postoji jedan Bog, već postoje mnoga božanstva & $-.101^{* * *}$ \\
\hline
\end{tabular}

*** $\mathrm{p}<0,01 ;{ }^{*} \mathrm{p}<0,05$. 
S druge strane, studenti SVZG-a skloniji su vjerovanju da „ne postoji Bog, ali postoji nešto nadzemaljsko“, da „ljudi žive u svemiru koji je umjetna tvorevina superiornih bića“ te da „čovjek nije stvoren na sliku Božju, već je proizvod kozmičke slučajnosti“ i da „ne postoji jedan Bog, već postoje mnoga božanstva“. U nastavku analize na ovom instrumentu sustava vjerovanja proveli smo faktorsku analizu.

Faktorskom analizom pod komponentnim modelom s varimax rotacijom latentnih osi na instrumentu vjerovanja dobivene su četiri latentne dimenzije, odnosno četiri faktora. S obzirom na saturacije pojedinih tvrdnji prvi faktor nazvali smo „kršćansko vjerovanje“, drugi faktor nazvali smo „kozmička ireligija“, a treći i četvrti faktor, koji obuhvaćaju praznovjerje nazvali smo „praznovjerje - nadnaravno“ i „praznovjerje stereotipi“. Faktorska analiza inicijalno je provedena na svim česticama instrumenta, a nakon toga u drugom koraku izostavljene su dvije čestice jer nisu zadovoljavale kriterij jednostavne strukture. ${ }^{14}$

Tablica 16.

Matrica varimax faktora. Dimenzije vjerovanja.

\begin{tabular}{|c|c|c|c|c|}
\hline & $\begin{array}{l}\text { KRŚĆANSKO } \\
\text { VJEROVANJE }\end{array}$ & $\begin{array}{l}\text { KOZMIČKA } \\
\text { IRELIGIJA }\end{array}$ & $\begin{array}{l}\text { PRAZNOVJERJE- } \\
\text { NADNARAVNO } \\
\end{array}$ & $\begin{array}{l}\text { PRAZNOVJERJE- } \\
\text { STEREOTIPI } \\
\end{array}$ \\
\hline Biblija je doista riječ Božja & .890 & & & \\
\hline Postoje raj i pakao & .883 & & & \\
\hline $\begin{array}{l}\text { Na kraju vremena Krist će ponovo doći } \\
\text { na Zemlju }\end{array}$ & .875 & & & \\
\hline Crkva je stvorena od Boga & .870 & & & \\
\hline Postoji Bog kao osoba & .818 & & & \\
\hline Čovjek ima besmrtnu dušu & .775 & & & \\
\hline $\begin{array}{l}\text { Čovjek nije stvoren na sliku Božju, već } \\
\text { je proizvod kozmičke slučajnosti }\end{array}$ & -.746 & & & \\
\hline $\begin{array}{l}\text { Ne postoji Bog, ali postoji nešto } \\
\text { nadzemaljsko }\end{array}$ & -.476 & .602 & & \\
\hline $\begin{array}{l}\text { Ljudi žive u svemiru koji je umjetna } \\
\text { tvorevina superiornih bića }\end{array}$ & & .711 & & \\
\hline $\begin{array}{l}\text { Postoji mnoštvo beskrajnih svemira } \\
\text { kojima upravljaju bića superiorne } \\
\text { inteligencije }\end{array}$ & & .702 & & \\
\hline $\begin{array}{l}\text { Osnovno Božje svojstvo je periodična } \\
\text { promjenjivost Dobra i Zla }\end{array}$ & & .671 & & \\
\hline $\begin{array}{l}\text { Ne postoji jedan Bog, već postoje } \\
\text { mnoga božanstva }\end{array}$ & & .620 & & \\
\hline $\begin{array}{l}\text { Neke osobe mogu stupiti u kontakt s } \\
\text { mrtvima }\end{array}$ & & & .843 & \\
\hline $\begin{array}{l}\text { Postoje ljudi koji mogu baciti urok ili } \\
\text { prokletstvo }\end{array}$ & & & .739 & \\
\hline U duhove & & & .706 & \\
\hline U radiesteziju i bioenergiju & & & .551 & \\
\hline 13 je nesretan broj & & & & .867 \\
\hline Horoskop točno predviđa budućnost & & & & .675 \\
\hline
\end{tabular}

Ekstrabirani faktori tumače 64,24\% varijance.

${ }^{14}$ U drugom koraku faktorske analize izostavljene su sljedeće čestice: „Vjerovanje u reinkarnaciju, tj. ponovno rađanje na ovome svijetu“ i „Svijetom vlada kozmička inteligencija“. 
Dobivene faktore analizirali smo s obzirom na osnovne sociodemografske karakteristike i političke orijentacije ispitanih studenata. Rezultati regresijske analize pokazuju jasnu statističku značajnost odabranih prediktora tek na prvom faktoru („kršćansko vjerovanje“), gdje odabrani prediktori tumače 32,9 posto kriterijske varijable, no tek uz jedan značajan prediktor, a to su političke orijentacije.

Ispitani studenti desnih političkih orijentacija skloniji su „kršćanskom vjerovanju“. Statistička značajnost dobivena je i na drugom faktoru („kozmička ireligija“), no uz samo 3,5 posto protumačene varijance kriterija i dva relativno značajna prediktora - spol i političke orijentacije. Studenti lijevih političkih orijentacija skloniji su „kozmičkoj ireligiji“.

Tablica 17.

Dimenzije vjerovanja s obzirom na sociodemografske karakteristike i političke orijentacije.

\begin{tabular}{|c|c|c|c|c|c|}
\hline & & $\begin{array}{l}\text { standardizirani } \\
\text { koeficijenti }\end{array}$ & \multirow{2}{*}{$p$} & \multicolumn{2}{|c|}{ korelacije } \\
\hline & & beta & & direktne & parcijalne \\
\hline \multirow[t]{2}{*}{$\begin{array}{l}\text { KRŠĆANSKO } \\
\text { VJEROVANJE }\end{array}$} & $\begin{array}{l}\text { Političke } \\
\text { orijentacije }\end{array}$ & .562 & $<.001$ & .556 & .565 \\
\hline & \multicolumn{5}{|l|}{$\mathrm{R}^{2}=.329$} \\
\hline \multirow{3}{*}{$\begin{array}{l}\text { KOZMIČKA } \\
\text { IRELIGIJA }\end{array}$} & Spol & -.142 & $<.001$ & -.136 & -.143 \\
\hline & $\begin{array}{l}\text { Političke } \\
\text { orijentacije }\end{array}$ & -.129 & $<.001$ & -.123 & -.130 \\
\hline & \multicolumn{5}{|l|}{$R^{2}=.035$} \\
\hline \multirow[t]{2}{*}{$\begin{array}{l}\text { PRAZNOVJERJE- } \\
\text { NADNARAVNO }\end{array}$} & Spol & .133 & $<.001$ & .139 & .133 \\
\hline & \multicolumn{5}{|l|}{$\mathrm{R}^{2}=.023$} \\
\hline \multirow[t]{2}{*}{$\begin{array}{l}\text { PRAZNOVJERJE- } \\
\text { STEREOTIPI }\end{array}$} & Spol & -.114 & $<.001$ & -.114 & -.114 \\
\hline & \multicolumn{5}{|l|}{$\mathrm{R}^{2}=.013$} \\
\hline
\end{tabular}

Iznimno niska statistička značajnost dobivena je i na dvama faktorima koja sadržajno obuhvaćaju praznovjerje, gdje se kao relativno značajan prediktor javlja spol. Studentice su sklonije dimenziji praznovjerja koju smo nazvali „praznovjerje - nadnaravno“, a studenti su skloniji dimenziji „praznovjerje - stereotipi“.

Dobivene latentne dimenzije vjerovanja analizirali smo i s obzirom na pripadnost fakultetu, odnosno sveučilištu. 
Tablica 18.

Dimenzije vjerovanja s obzirom na pripadnost fakultetu/sveučilištu.

\begin{tabular}{|c|c|c|c|c|}
\hline & & M & \multirow{5}{*}{$\begin{array}{c}F=64,670 \\
\text { sig. } p<0,001\end{array}$} & kontrast \\
\hline \multirow{4}{*}{$\begin{array}{l}\text { KRŠĆANSKO } \\
\text { VJEROVANJE }\end{array}$} & FFZG & -.51228 & & \multirow{4}{*}{$\begin{array}{l}\text { HKS > ostali; } \\
\text { FFZG < ostali }\end{array}$} \\
\hline & HKS & .43348 & & \\
\hline & FSB & -.08987 & & \\
\hline & MEF & -.21268 & & \\
\hline & & M & \multirow{5}{*}{$\begin{array}{c}\mathrm{F}=8,601 \\
\text { sig. } \mathrm{p}<0,001\end{array}$} & kontrast \\
\hline \multirow{4}{*}{$\begin{array}{l}\text { KOZMIČKA } \\
\text { IRELIGIJA }\end{array}$} & FFZG & .12380 & & \multirow{4}{*}{ FFZG, FSB > HKS } \\
\hline & HKS & -.14273 & & \\
\hline & FSB & .22645 & & \\
\hline & MEF & .04346 & & \\
\hline & & M & \multirow{5}{*}{$\begin{array}{c}F=35,519 \\
\text { sig. } p<0,001\end{array}$} & kontrast \\
\hline \multirow{4}{*}{$\begin{array}{l}\text { PRAZNOVJERJE - } \\
\text { NADNARAVNO }\end{array}$} & FFZG & .21127 & & \multirow{4}{*}{$\begin{array}{c}\text { FFZG, } \\
\text { HKS }>\text { FSB, }\end{array}$} \\
\hline & HKS & .25011 & & \\
\hline & FSB & -.28099 & & \\
\hline & MEF & -.37287 & & \\
\hline & & M & \multirow{5}{*}{$\begin{array}{c}F=6,374 \\
\text { sig. } p<0,02\end{array}$} & kontrast \\
\hline \multirow{4}{*}{$\begin{array}{l}\text { PRAZNOVJERJE - } \\
\text { STEREOTIPI }\end{array}$} & FFZG & -.10183 & & \multirow{4}{*}{ FSB $>$ ostali } \\
\hline & HKS & -.05587 & & \\
\hline & FSB & .25775 & & \\
\hline & MEF & -.02053 & & \\
\hline
\end{tabular}

Rezultati analize varijance pokazuju da su studenti HKS-a skloniji „kršćanskom vjerovanju“, za razliku od svih ostalih. Studenti FFZG-a i FSB-a skloniji su „kozmičkoj ireligiji“, za razliku od studenata HKS-a. Studenti FFZG-a i HKS-a skloniji su dimenziji „praznovjerje - nadnaravno“, za razliku od studenata FSB-a i MEF-a, a studenti FSB-a skloniji su dimenziji „praznovjerje - stereotipi“, za razliku od svih ostalih.

Na kraju analize, a prije zaključka, kratko ćemo provjeriti u radu postavljene hipoteze s obzirom na dobivene rezultate.

Prva radna hipoteza pretpostavljala je da su studenti HKS-a skloniji kršćanskoj religioznosti u usporedbi sa studentima SVZG-a. Dobiveni rezultati potvrđuju tu hipotezu: 35,9 posto studenata HKS-a smatra se „religioznima u skladu s crkvenim učenjem“, za razliku od njih 15,6 posto na SVZG-u, a rezultati hi-kvadrat testa pokazuju statističku značajnost u tom smislu. Na HKS-u je 43,1 posto „vjernika praktikanata“, a na SVZG-u ih je 23,5 posto. Rezultati hi-kvadrat testa također potvrđuju statistički značajnu razliku po tom pitanju. S obzirom na sustav vjerovanja, više od polovice studenata HKS-a iskazuje vjerovanje na svim česticama koje sadržajno obuhvaćaju neke od ključnih religijskih istina kršćanstva, dok je na istim česticama iskazano vjerovanje studenata SVZG-a znatno manje. Rezultati korelacijske analize potvrđuju statistički značajne razlike. 
Druga radna hipoteza pretpostavljala je da su studentice sklonije religioznosti na svim ispitivanim dimenzijama u odnosu na studente. Dobiveni rezultati ne potvrđuju tu hipotezu. Naime rezultati regresijske analize pokazuju statistički značajne razlike s obzirom na spol po pitanjima religijske samoidentifikacije i institucionalne religijske prakse, ali ne i po pitanju kršćanskog vjerovanja.

I na kraju, treća radna hipoteza pretpostavljala je snažnu povezanost kršćanske religioznosti i političkih orijentacija studenata. Dobiveni rezultati potvrđuju tu hipotezu. $\mathrm{Na}$ svim ispitivanim dimenzijama religioznosti (religijska samoidentifikacija, institucionalna religijska praksa, kršćansko vjerovanje) dobivena je snažna povezanost s političkim orijentacijama. Politički desno orijentirani studenti skloniji su kršćanskoj religioznosti.

U zaključku koji slijedi prvo ćemo analizirati opravdanost polazne pretpostavke ovog rada, navesti nedostatke i ograničenja naše analize, a zatim ćemo pokušati dati odgovore na pitanja postavljena u uvodu.

\section{Zaključak}

Polazna pretpostavka ovog rada postojanje je sukladnosti religijskih promjena kod dijela zagrebačkih studenata s onima kod opće populacije u Hrvatskoj. U konkretnom smislu to znači visoku razinu religijske samoidentifikacije, relativnu stabilnost institucionalne religijske prakse, uz određeni pad vjerovanja u temeljne religijske istine, te istovremeno relativno stabilnu prisutnost individualizirane religioznosti i „alternativne religioznosti“. Dobiveni rezultati ukazuju na opravdanost polazne pretpostavke, no ukazuju također i na određene razlike u religioznosti zagrebačkih studenata i opće populacije. Primjerice, kod religijske samoidentifikacije znatno manji postotak ispitanih studenata (68,3 posto) smatra se religioznima u odnosu na populaciju ( 87,7 posto), a posebice su primjetne razlike ako promatramo one koji se smatraju „religioznima u skladu s crkvenim učenjem“ (23,4 posto kod ispitanih studenata naspram 47,2 posto u populaciji). Individualizirana religioznost u tom smislu (oni koji se smatraju „religioznima na svoj način“) na sličnoj je razini i kod ispitanih studenata i kod populacije. S obzirom na institucionalnu religijsku praksu, rezultati kod ispitanih studenata nešto su viši nego kod populacije ako promatramo tjedne odlaske u crkvu na misu (31,0 posto kod studenata u odnosu na 22,9 posto kod populacije). Budući da u prvom valu našeg istraživanja nismo imali instrumente koji mjere religijsku samoidentifikaciju i institucionalnu religijsku praksu, o religijskim promjenama kod zagrebačkih studenata u tom smislu ne možemo ništa zaključiti. Kod sustava vjerovanja primjetan je pad vjerovanja u neke od osnovnih istina kršćanstva, što je u skladu s religijskim promjenama u populaciji (Črpić, Zrinščak, 2010.:14) te također prisutnost određenih elemenata tzv. „alternativne religioznosti“, koji u ovom istraživanju sadržajno obuhvaćaju dijelove praznovjerja i jedne nekršćanske duhovnosti.

U vezi nedostataka i ograničenja naše analize u ovom radu moramo istaknuti da je empirijsko istraživanje provedeno na prigodnom uzorku zagrebačkih studenata, te 
dobivene rezultate nije moguće generalizirati na sve zagrebačke studente, cijelu populaciju studenata u Hrvatskoj, kao ni na opću populaciju Hrvatske. S tim u vezi sve takve usporedbe u radu tek su potencijalno indikativne i ne mogu voditi do snažnije utemeljenih zaključaka. Također, u komparativnoj analizi religioznosti zagrebačkih studenata nedostaje nekoliko važnih pitanja kao što su primjerice konfesionalna pripadnost (u obama valovima istraživanja), religijska samoidentifikacija i institucionalna religijska praksa (u prvom valu istraživanja). Navedeni nedostaci proizlaze iz osnovne teme istraživanja koja obuhvaća studentske stavove o različitim bioetičkim pitanjima kao što su pobačaj, eutanazija, medicinski potpomognuta oplodnja i genetički inženjering. Stoga je i broj mjernih instrumenata za područje religioznosti bio znatno ograničen. Također, navedeni nedostaci smanjuju analitički potencijal i ostavljaju mnoga pitanja otvorenima, no ipak smatramo da se i kroz takvu fragmentiranu i nejasnu sliku religioznosti ispitanih zagrebačkih studenata mogu nazrijeti određene indicije religijskih promjena.

Dakle ispitani zagrebački studenti imaju nižu razinu religijske samoidentifikacije od opće populacije (posebice u smislu institucionalizirane religioznosti), kod njih je kao i kod opće populacije primjetan pad vjerovanja u neke od ključnih religijskih istina kršćanstva, također je primjetna prisutnost individualizirane religioznosti i nekih elemenata „alternativne religioznosti“, no razina tjednih odlazaka u crkvu na misu viša je nego kod opće populacije. Što uopće možemo zaključiti iz dobivenih rezultata? U promatranom razdoblju između 2005. i 2017. godine došlo je do vrlo jasnog opadanja vjerovanja u neke od ključnih religijskih istina kršćanstva kod ispitanih zagrebačkih studenata. Budući da komparativna analiza rezultata za opću populaciju u razdoblju od 1999. do 2008. godine pokazuje sličan trend (iako je razina vjerovanja u ključne religijske istine kršćanstva kod opće populacije na višoj razini nego kod ispitanih studenata), to upućuje na zaključak da će se proces opadanja kršćanskog vjerovanja u hrvatskom društvu nastaviti, što bi onda trebali i potvrditi rezultati EVS-a za 2017. godinu. Označava li to i početak procesa smanjivanja religioznosti u općem smislu u hrvatskom društvu teško je jednoznačno i sa sigurnošću ustvrditi. Ono što pak sa određenom sigurnošću možemo reći jest da nam u sociologiji religije sve više nedostaju teorijski koncepti u analizi suodnosa suvremenih društvenih i religijskih promjena. Teorijski koncepti koji primjerice pretpostavljaju da kada je nečega više (modernizacije), onda nečega mora biti manje (religije) ili da religija može opstati u modernom društvu samo ako preuzme nereligijske uloge (Bruce, 2002.) jednostavno nisu dostatni. Religija je područje koje prije svega teži ispuniti ljudske potrebe za utjehom i nadom i posljedično određenim smislom života koji nadilazi imanentno. A te ljudske potrebe neće nestati čak ni u izrazito tehnološkom okružju suvremenog društva, koje otvara gotovo beskrajne mogućnosti ugode i sreće. No načini ispunjavanja tih potreba mijenjali su se tijekom razvoja društva, nekad brže a nekad znatno sporije, te će se mijenjati i dalje. U tom smislu dolazi i do promjene shvaćanja i prakticiranja religije, na što ukazuje i dio dobivenih rezultata u ovom radu. S druge strane, dobiveni rezultati pokazuju da kod ispitanih zagrebačkih studenata postoji snažna povezanost religioznosti i političkih orijentacija, što možemo promatrati kao posljedicu ne samo svjetonazorskih sukoba i kulturnih ratova u posljednjih pet - šest godina u hrvatskom društvu, već i jednog „refleksa devedesetih“, kada je spoj nacionalnog i religijskog, barem u javnom diskursu, bio izrazito važan 
okvir konstrukcije identiteta. Pritom je ipak važno upozoriti da ta svojevrsna religijska uloga „kulturne obrane“ (Bruce, 2002.), bez obzira na sve prijepore i probleme suvremenog hrvatskog društva i bez obzira na potencijalnu zavodljivost i prividnu sigurnost "homogenizacije protiv“, ne može biti dugotrajna niti dugotrajno može pridonijeti razvoju društva i religije unutar tog društva.

\section{Literatura}

1. Casanova, J. (1994). Public Religions in the Modern World. Chicago \& London: Chicago University Press.

2. Baloban, J.; Nikodem, K. i Zrinščak, S. (Ur.) (2014). Vrednote u Hrvatskoj i u Europi; Komparativna analiza. Zagreb: Kršćanska sadašnjost, KBF Sveučilišta u Zagrebu.

3. Berger, P. (1990). The Sacred Canopy. Elements of a Sociological Theory of Religion. New York: Anchor Books.

4. Berger, Peter (Ed.) (1999). The Desecularization of the World. Resurgent Religion and World Politics. Grand Rapids, Eerdmans.

5. Berger, P. (2002). Secularization and de-secularization, in: Woodhead, L. et al. (Eds.). Religions in the Modern World. Traditions and Transformations. London: New York, Routledge: 291-298.

6. Beyer, P. (1994). Religion and Globalization. London: Sage.

7. Boneta, Ž. (2016). Klatno se i dalje njiše. Institucionalna religioznost riječkih studenata. Sociologija i prostor, 206 (3): 265-294.

8. Bruce, S. (2002). God is Dead. Secularization in the West. Oxford: Blackwell Publishers.

9. Črpić, G. i Zrinščak, S. (2005). Između identiteta i svakodnevnog života. Religioznost u hrvatskom društvu iz europske komparativne perspektive, u: Baloban, J. (Ur.). U potrazi za identitetom. Komparativna studija vrednota: Hrvatska $i$ Europa. Zagreb: Golden marketing-Tehnička knjiga: 45-83.

10. Črpić, G. i Zrinščak, S. (2010). Dinamičnost u stabilnosti: religioznost u Hrvatskoj 1999. i 2008. godine. Društvena istraživanja, 19 (1-2): 3-27.

11. Dobbelaere, K. (2002). Secularization: An Analysis at Three Levels. Bruxelles: Peter Lang.

12. Habermas, J. (2008). Notes on Post-Secular Society. New Perspectives Quarterly, 25 (4): 17-29.

13. Hjelm, T. (Ed.) (2015). Is God Back? Reconsidering the New Visibility of Religion. London: Bloomsbury Academic.

14. Ilišin, V. i Radin, F. (Ur.) (2002). Mladi uoči trećeg milenija. Zagreb: IDIZ, Državni zavod za zaštitu obitelji, materinstva i mladeži.

15. Ilišin, V. i Radin, F. (Ur.) (2002). Mladi: problem ili resurs. Zagreb: IDIZ.

16. Ilišin, V. i drugi (2013). Mladi u vremenu krize. Zagreb: IDIZ, Friedrich Ebert Stiftung.

17. Ilišin, V. (Ur.) (2014). Sociološki portret hrvatskih studenata. Zagreb: IDIZ.

18. Ilišin, V. (2014). Uvod u istraživanje hrvatskih studenata, u: Ilišin, V. (Ur.). Sociološki portret hrvatskih studenata. Zagreb: IDIZ: 11-28. 
19. Luckmann, T. (1967). The Invisible Religion. The problem of Religion in Modern Society. New York: The Macmillan Company.

20. Marinović Jerolimov, D. (2002). Religioznost, nereligioznost i neke vrijednosti mladih, u: Ilišin, V. i Radin, F. (Ur.). Mladi: problem ili resurs. Zagreb: IDIZ: 79124.

21. Marinović Jerolimov, D. (2005). Tradicionalna religioznost u Hrvatskoj 2004: između kolektivnog i individualnog. Sociologija sela, 168 (2): 303-339.

22. Marinović Jerolimov, D. i Jokić, B. (2010). Religion and Youth in Croatia, in: Giordan, G. (Ed.). Annual Review of the Sociology of Religion. Volume 1. Youth and Religion. Leiden, Boston, Brill: 307-327.

23. Martikainen, T. and Gauthier, F. (2013). Religion in the Neoliberal Age. Political Economy and Modes of Governance. Aldershot: Ashgate.

24. Nikodem, K. (2004). Religijski identitet u Hrvatskoj. Dimenzije religijskog identiteta i socio-ekološke orijentacije. Socijalna ekologija, 13 (3-4): 257-285.

25. Nikodem, K. (2005). Genetički inženjering i nova duhovnost. Smisao života i smrti u poslijeljudskom kontekstu. Socijalna ekologija, 14 (3): 171-193.

26. Nikodem, K. (2011). Religija i crkva; Pitanja institucionalne religioznosti u suvremenom hrvatskom društvu. Socijalna ekologija, 20 (1): 5-30.

27. Nikodem, K. and Zrinščak, S. (2012). Croatia's Religious Story: the coexistence of institutionalized and individualized religiosity, in: Pollack, D.; Mueller, O. and Pickel, G. (Eds.). The Social Significance of Religion in the Enlarged Europe; Secularization, Individualization and Pluralization. Aldershot: Ashgate: 207-227.

28. Pew Research Center (2017). Religious Belief and National Belonging in Central and Eastern Europe.

29. Rimac, I. (2014). Komparativni pregled odgovora u anketi Europska studija vrednota 1999. i 2008, u: Baloban, J.; Nikodem, K. i Zrinščak, S. (Ur.). Vrednote u Hrvatskoj i u Europi; Komparativna analiza. Zagreb: Kršćanska sadašnjost, KBF Sveučilišta u Zagrebu: 309-473.

30. Turner, B. (1991). Religion and Social Theory. London: Sage.

31. Vrcan, S. (1999). Novi izazovi za suvremenu sociologiju religije. Politizacija religije i religizacija politike u postkomunizmu. Revija za sociologiju, 30 (1-2): 45-64.

32. Wilson, B. (1966). Religion in Secular Society. A Sociological Comment. London: C.A. Watts \& CO LTD.

33. Zrinščak, S. (2001). Ima neka tajna veza. Religioznost mladih kao indikator društvenih i religijskih promjena. Društvena istraživanja, 10 (1-2): 19-40. 
Izvorni znanstveni rad

Krunoslav Nikodem

University of Zagreb, Faculty of Humanities and Social Sciences, Department of Sociology, Croatia e-mail:knikodem@ffzg.hr

Juraj Jurlina

Josip Juraj Strossmayer University of Osijek, Faculty of Philosophy, Sociology Studies, Croatia

e-mail: jjurlina@ffos.hr

\title{
In Anticipation of Declining Religiosity? Comparative Analysis of Religiosity among Zagreb Students
}

\begin{abstract}
The paper is based on the analysis of results obtained from the empirical research carried out from January to April 2017 on a convenience sample made up of students from the University of Zagreb and the Catholic University of Croatia $(\mathrm{N}=1270)$. A group administered survey was conducted with respondents from the first to the last year of studies at three faculties of the University of Zagreb (Faculty of Humanities and Social Sciences, Faculty of Mechanical Engineering and Naval Architecture, School of Medicine) and with students at four departments of the Catholic University of Croatia (Sociology, Psychology, History and Communication Studies). The purpose of the paper is to present the results of two empirical studies conducted in 2005 and 2017 on religiosity of Zagreb students. The general assumption is that religious changes among college students in Zagreb coincide with those of the general population of Croatia. The three working hypotheses are: (1) students at the Catholic University of Croatia are more inclined to Christian religiosity than students at the University of Zagreb, (2) female students are more inclined to Christain religiosity than their male counterparts and (3) Christian religiosity of students is strongly connected with their political orientation. The analysis results confirm the first and the third working hypothesis.
\end{abstract}

Key words: religiosity, students, political orientation, social changes, religious changes. 